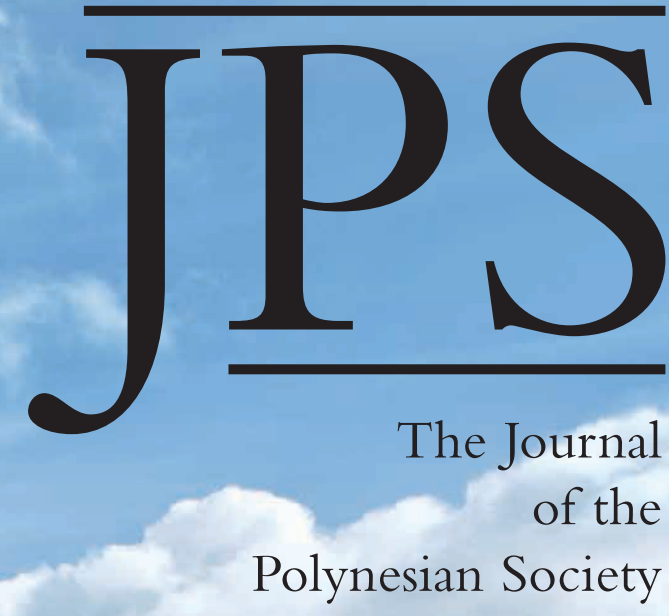

VOLUME 125 No.2 JUNE 2016

Special issue

GRAVE MATTERS IN OCEANIA

THE POLYNESIAN SOCIETY

THE UNIVERSITY OF AUCKLAND

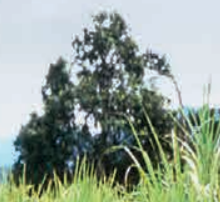

NEW ZEALAND

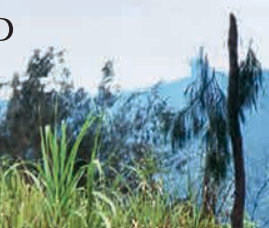

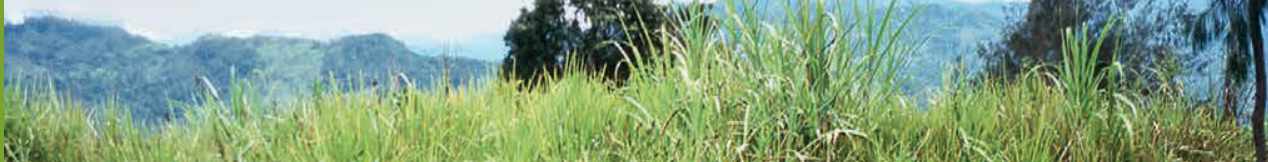

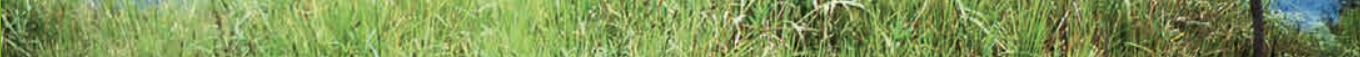

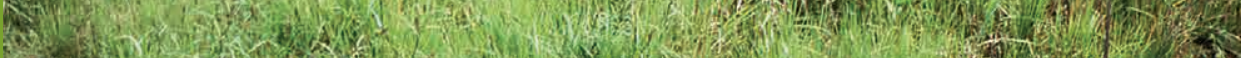

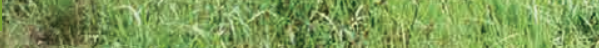




\title{
CHANGING MORPHOLOGY OF GRAVES AND BURIALS IN SAMOA
}

\author{
SA'ILIEMANU LILOMAIAVA-DOKTOR \\ University of Hawai ' $i$-West $O$ 'ahu
}

In this article, I investigate Samoan custom and the factors that influence decisions about graves, the location of grave sites, and the more recent option of cremation, in the context of migration and social change. I examine their impacts on Samoan understandings of fanuaoti and tu 'ugamau 'grave, tomb', fanuatanu 'cemetery, graveyard', and liutofaga 'reinterred' and fa 'aliuefuefu 'cremation', and I argue that the cultural modifications of burial and funeral rituals have been changed, but also reinvigorated, by the territorial redistribution of people in the Samoan diaspora. I argue that place as heritage/ identity as in fa 'asinomaga as well as the hegemony of place are brought to high relief on the occasion of the funeral, and elaborated in the diaspora. There is a Samoan saying o le tagata ma lona fa 'asinomaga 'a person and his or her heritage and identity', which refers to the rights of all Samoans in their ancestral villages, land and kindred, as well as carefully observed norms of respect, duty and obligation. It is this context that I situate my discussion of cultural, social, political and economic changing morphology of graves, burials and funerary customs. I argue that place as identity is intimately bound up with conceptions of kinship that define where 'aiga (forebears and other kin) are buried, fa 'asinomaga and fanua (land). Whether overseas or in Samoa, decisions about where to bury the dead are not easy, given the cultural and geographical centripetal and centrifugal factors, referring to both cultural ideas - Samoan and foreign - and geographical locations - in the homeland or overseas, that influence people's choices. Cremating the dead is a recent practice, available overseas but new to Samoa. It is a practice that Samoans at home and abroad are uncertain about and in Samoa it can be a contentious choice.

\section{CHANGING FUNERARY AND BURIAL PRACTICES}

One of the most important ritual events among Samoans is the fa 'alavelave, which literally means a 'disruption or interruption'. Of these, funerals are often the most elaborate. Samoan death and mourning rituals have many functions: helping individuals and families recover and return to regular life after their loss, reuniting kin, and sometimes demonstrating the wealth and high status of an extended family. Families make journeys to funerals of relatives to pay their respects, show their love and help with the funeral, 
bringing fine mats, pigs or cattle and cash to build up a store of reciprocal gifts that are central to the ceremonies. Relatives have special rights and duties at funerals, depending on whether they are related by blood or by marriage, and important relationships are marked by gifts of fine mats ( 'ie). These are named and given for the passing of a spouse ('ie o le mavaega) or a parent and children ('ie o le measulu), and to commemorate the duty of a deceased woman to her husband and his family ('ie o le fa 'amagaloga), the fine mat which connotes a request for forgiveness and pardon for any of her wrongdoings to them during her life. Another, the 'ie o le 'amiga, is given to mark the return of a surviving spouse to his or her own kin. According to Fofo Sunia (1997) Samoan protocol prescribes that these fine mats should not be kept, but politely returned; only the 'ie o le mavaega should be kept by those to whom it has been presented, because this is the farewell fine mat of a woman's family to her husband's family. ${ }^{1}$ Another important gift, given to deceased persons of high rank, is the 'ie o le afuelo, a fine mat to cover the coffin. Nowadays this is laid on the coffin when it is taken from the morgue. The decision as to who provides this mat is negotiated between the bereaved families, and is usually the gift of those related to the deceased by marriage. At the funeral rites, the same fine mat is presented to the $s e^{\prime} e$, a person of high rank who represents the branch of the ancestral family related through a brother and sister pair and has the traditional obligation to guard the body of the deceased until the burial (Simanu 2002, Sunia 1997). ${ }^{2}$ The se 'e traditionally brought an ufimata 'shroud', scented coconut oil and a fan as part of their role. Nowadays, ufimata includes bolts of expensive white cloth, satin or lace, symbolising shrouds and is presented by kinswomen of the deceased and the women of the village.

As the possibilities for large family gatherings and expensive ceremonies have increased owing to migration, funerals have become more elaborate both in Samoa and among overseas Samoans. In Samoa, until the early 1980s, the dead were buried immediately because there were no funeral homes with morgues to allow funerals to be prolonged. Funeral announcements were made on the radio and relatives throughout Samoa would collect up their gifts and come immediately to the village of the deceased to pay their respects. High chiefs' (ali 'i) funerals are termed lagi and, as a sign of respect, tu 'ilauniu 'cut branches of green coconut leaf' are stuck in the ground alongside the village road all the way to the deceased faletalimalo 'guest house' where the funeral is held. Church choirs and their ministers, who come to offer hymns and prayers to the bereaved family, attend most funerals. If the village has several churches, a number of choirs may attend, one following the other, and each choir is given food to thank them. When I 
was a young person living in Samoa and attending a funeral with my choir, the family gave us big kettles of tea, cartons of biscuits, a block of butter and a bottle of jam. ${ }^{3}$

Everyone in the extended family has a duty to perform: there is the bookkeeper usually a sister or daughter of resident matai chosen because she is knowledgeable about kinship relations of the 'aiga 'extended families' and must account for what comes in and goes out. The women of the family prepare food; the daughters and sisters of the family sort the fine mats, bark cloths (tapa) and mats to be given as reciprocal gifts and also present the fine mats and special gifts that accompany them; the young men butcher and prepare pigs and cattle, and carry forward and distribute heavy gifts such as meat and cartons of canned fish and meat; the elders and the titled heads of families (matai), and the sisters of the deceased receive and return gifts, acknowledging them with appropriate oratory.

In Samoan villages only the chiefs of a village are buried in tombs at the sides the once sacred space at the centre of the village (malae) adjacent to their traditional house sites (maota). The term for a traditional chiefly grave monument is tia, which Aumua Mata'itusi (pers. comm., 7 October 2015) explained comes from the word atutia that in dignified Samoan speech refers to a mountain range. The term for a mausoleum is $l o a$, which comes from the word va 'aloa, the term for the ghost canoe in which souls were once believed to be ferried to another world, and in the old days was specially designed to carry a deceased chief to his grave. These terms signify reverence for high rank village hierarchy; ordinary graves are termed fanuaoti and tu 'ugamau (see Fig. 1). In some villages, members of the clergy may also be buried on the malae, or adjacent to a church. In the colonial period other people were buried in village cemeteries or family graveyards (see Meleisea and Schoeffel, this volume). Graves are cared for and decorated during the year of mourning, and in that year at the annual White Sunday service, which is dedicated to children, families commemorate their dead with songs or plays in their memory. Today, many families hold an 'unveiling' ceremony (talagāteu) to a mark the first anniversary of a funeral. Sometimes a headstone is also installed during this time (see Fig. 2). ${ }^{5}$ Over the years these ceremonies have become more elaborate, with ceremonially presented gifts of fine mats and cash exchanged between families and their church ministers, as well as food for everybody who attends. Like the change in the style and location of graves and funerary customs, tombstones, which for most people were once modest cement or stone rectangles, have become increasingly elaborate (see Meleisea and Schoeffel, this volume). 


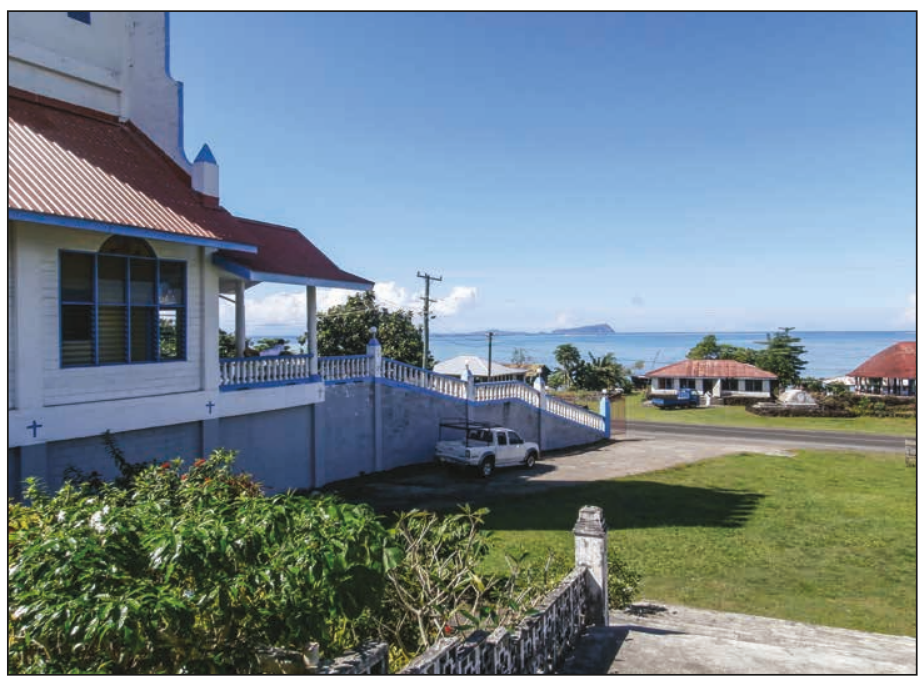

Figure 1a. Grave site of ali $i$ in malae from late 19th century at Foua, Salelologa 2013.

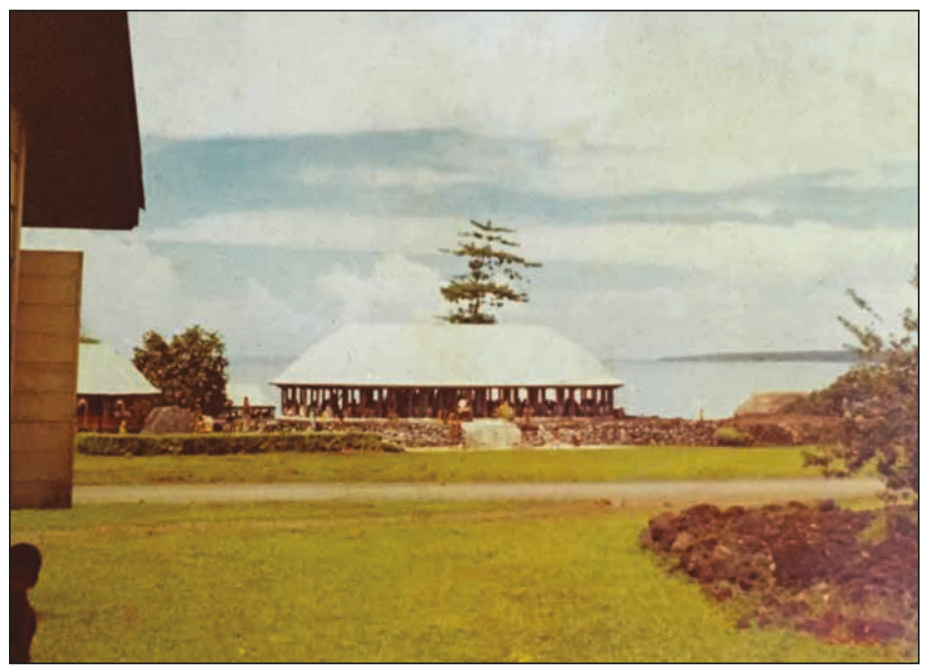

Figure 1b. Same grave site of ali $i$ at Foua, Salelologa (photo taken in 1973). 


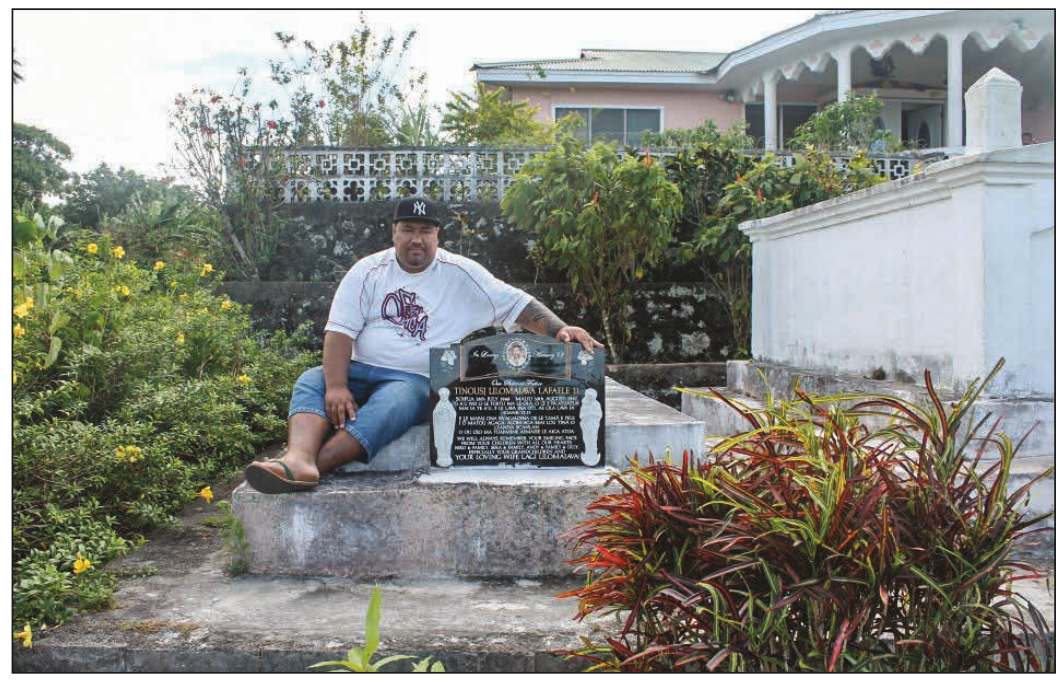

Figure 2. Modern grave with headstone 2005.

\section{THE SAMOAN DIASPORA AND FUNERARY CUSTOMS}

In Samoa today not only do people in the country try to attend funerals of their relatives, but relatives come from American Samoa and overseas as well, all bringing their contributions. Accordingly, funerals have become much more elaborate since the 1970s. The practice of keeping bodies refrigerated in morgues began in the 1970s when relatives who had gone overseas insisted on coming home to pay their last farewell. There were no direct flights to Samoa then as there are today (Simanu-Klutz 2001). At that time, only the main hospital in Apia had a small morgue (Lei'ataua Ala'ilima, 'Aumua Mata'itusi Simanu and Fa'alenu'u Lilomaiava pers. comms, July 2014).

In the early years of migration (1950s-1970s), younger people were sent overseas, mainly to earn money to raise the status of the 'äiga at home (Meleisea 1989). It was not thought of as an individual enterprise in which people migrated to improve their own lives. Those sent aboard worked in factories and sent money home to their parents to help build a modern house of permanent materials, or to rebuild a faletalimalō 'guest house', or to start a village shop, or to enable their families to contribute to community projects, such as school buildings and churches. In most cases, the parents of immigrants never thought of leaving Samoa. When those left behind died, 
their children and grandchildren, their siblings and cousins overseas asked for the funeral to be delayed so they could travel to bid final farewell.

Despite the ideal that fa 'asinomaga determines a burial place, the power of the ties established in the new lands of Samoans in New Zealand, Australia and the United States has increasingly influenced decisions made by Samoan families. Children living overseas increasingly make the decisions about funerals of their parents in Samoa. In my conversations with overseas Samoans about their decision on where their parents were buried it was apparent that from the early years of the 1970s and into the 80 s, when there was a larger outflow of migrants, funerals were more likely to be held in Samoa. However, as the years passed, overseas Samoan communities grew and became established, funerals were increasingly held overseas, with a reverse movement of kin travelling from Samoa to attend funerals overseas. However, indigenous notions of place and fa 'asinomaga continue to play a role in decisions about funerals and burial places. This can create a dilemma depending where people die. Those who pass away in New Zealand may hope that their graves will be located close to where their children and other close relatives live (Fig. 3), or they may wish to be buried in their home village. For example in my own family, my aunt Tapu'itea lived with her children in American Samoa. She died in 1978 and had asked to be returned to Samoa when she died, to the village where her brother (my father) lived and was matai of her 'áiga. In another instance a matai, Luamanuvae Milo, who died in 1991 after living for more than 30 years in Los Angeles, asked for his remains to be to be returned to Samoa to be buried, as did my relative

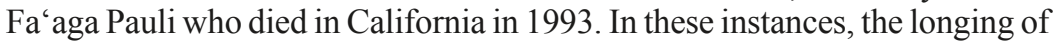
these elders to be returned to their birth place were deciding factors, despite the presence of children overseas and the years they had lived overseas. In contrast, a Samoan elder who died 1983, who had been a respected deacon and pioneer of his church community in Auckland, was buried in Waikumete Cemetery in Auckland, New Zealand. This decision was influenced by the consideration that his first wife was buried that cemetery and that his three children were born in New Zealand. Yet despite the distance and location, the funeral ceremony was conducted as it would have been in Samoa. The only difference was that his immediate family and his parish church played the role of a village to support his 'äiga, and the magnitude of the feast and the associated ceremonies were greater. When my cousin Lifa Leilua died in 1984, she too was buried in an Auckland cemetery and my mother travelled to her funeral from Samoa.

In recent times, a traditional funeral has become so expensive in Samoa that some death notices broadcast on radio or TV (using carefully chosen polite words) say that no Samoan customs are to be observed, evidently to 


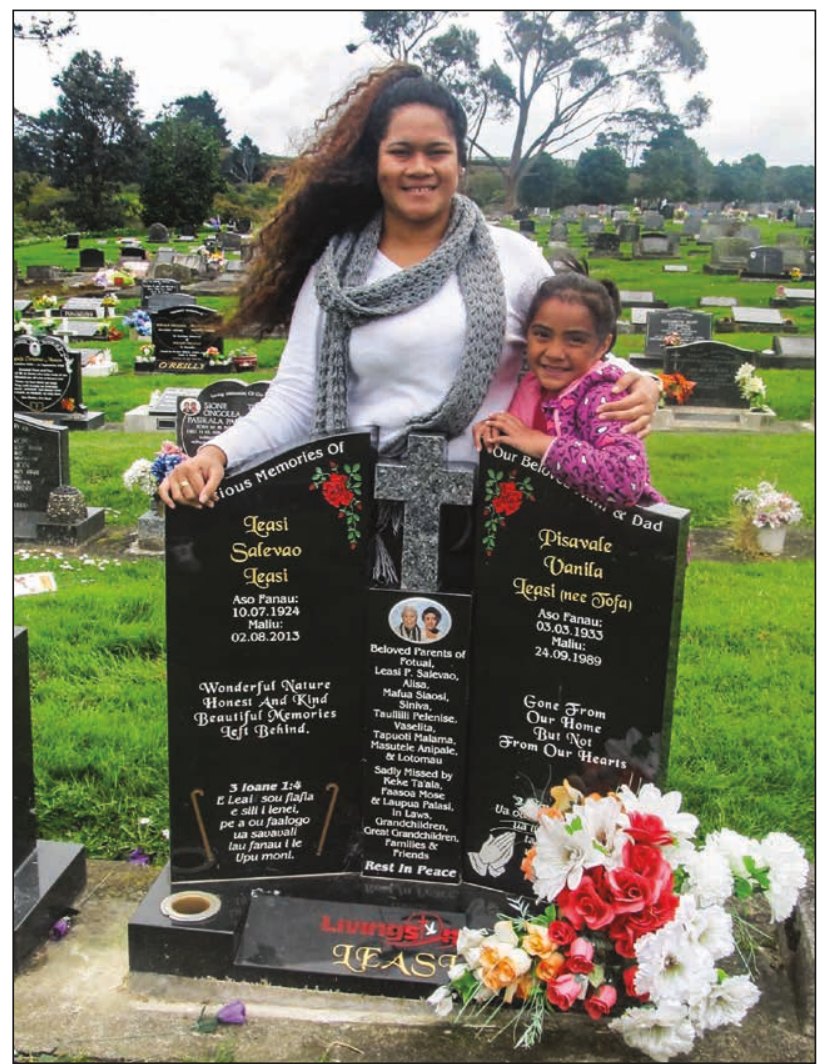

Figure 3. Grandchildren visiting grandparents' graves in Auckland.

reduce the expense. To hold an expensive traditional funeral may depend on the willingness of family members overseas to pay for it. However, expensive funerals continue to be the norm; demonstrating a family's wealth and, in some instances, raising the status of the family in the village. A well-managed funeral can reduce the risk of the family going into debt. An 'äiga decides how much to spend depending on the status of the deceased in the family and village, and often whether they want to make a statement about the status of their family. Although a funeral demonstrates love for the deceased, the economics of the funeral are important, the social and political power measured in the esteem that a family receives when the guests, relatives and 
the village return happy and replete with food, cash and fine mats from the funeral, and discuss among themselves how well everything was done. This is an example of Bourdieu's notion (1984) of symbolic capital and demonstrates how in Samoan eyes the rewards of symbolic capital can outweigh the cost of economic capital. The funeral and its execution is key to maintaining and enhancing 'aiga status. Now that funerals can no longer be provided from a subsistence economic base, families typically incur large debts by opening accounts with stores, which expect enough money will be received from si ' $i$ alofa (referring to gifts received from those attending the funeral) so that after all the expenses and reciprocations - cash, goods and fine matshave been accounted for, there will still be sufficient money to pay what is owed. If these funds are not sufficient, the extended family is expected to pay off the outstanding debts, an obligation that in practice usually falls on the children of the deceased. For this they win high esteem by showing lima malosi 'strong hands' and lima foa ' $i$ 'giving hands'. Debt sometimes provokes tensions in families about the accountability and transparency of matai, chiefs and orators of 'aiga, and of the family member entrusted as the funeral bookkeeper.

\section{FUNERAL BUSINESSES IN SAMOA}

Funerals have become times for the multi-national assembly of 'aiga, which has greatly influenced the extent, and magnitude, of funeral fa alavelave. Nowadays in Samoa, when most people die their bodies are embalmed to await the arrival and the participation of overseas relatives in the funeral. As previously noted, until the 1970s in Samoa all aspects of attendance upon the dead was done by the family and until late in that decade the only option to delay burial was to pay a small fee to the morgue at the main government hospital in Apia. Initially it could keep only six bodies, but by the 1980s had it increased its capacity to 20 . At that time the hospital was short of resources and there were many complaints about the quality of preservation and, as the demand grew, the hospital became less able to cope (Andrea Williams, Moto'otua, Apia, pers. comm. 23 August 2015). In 1985, Letoa Pa'u Sefo and Ana $\mathrm{Pa}^{\prime} \mathrm{u}$ established the first morgue, Sefo Pa'u Funeral Services, in Samoa to meet the growing need, beyond that available at the hospital, to embalm bodies and refrigerate them, awaiting the arrival of family members from overseas (pers. comm. 24 August 2015). Letoa said that better morgues were needed to provide this service, and that:

Up to early 1980 most people who died were buried immediately, especially in Savai'i Island. Since we had faleoti [morgues], whenever there's a death, the 'aiga tell the children overseas and they will always call, not to bury their mother or father until they arrive... [they would] call crying on the phone, 
Samoan love is strong. We have been busy since we opening there is not a day that we haven't had a body in there.

Letoa explained that he and another funeral service provider, Fesili Funeral Services, began their services in premises opposite the hospital but had no room there to expand as demand for services grew. Initially his business was just the morgue, and then they added a small foyer as a waiting area. He then moved to another location in Apia so he could offer more services. He explained:

The next minute the pastor was there and families just say prayers, a hymn, so [chapel services were] demanded of us. You see now, there is invariably a family service at the morgue before the body is taken to the home village where more church and cultural protocols of funeral are conducted. This new location, the buildings are spacious, has more shelves, and we have a viewing room, a chapel and seating area, and space to park vehicles.

During the interview with Letoa it became evident that his services are in high demand, with people coming in to change the dates of funerals and to extend the period that their deceased relative would remain in the morgue and to get certificates so they could take time off work.

There are now three funeral service providers: Sefo Funeral Services established in 1985, Fesili Funeral Transportation in 1986, and Ligaliga Funeral Services established in 1994. Letoa said that for a time his business provided a small selection of basic caskets, but these are now supplied by other businesses, which also supply wreaths and bouquets made from artificial flowers. He commented that in the last 20 years the basic kinds of caskets available were black or white, or the American laminated type with an open lid, remarking that families spend a lot of money on those caskets.

\section{CREMATION AND SAMOAN RESPONSES}

From a practical perspective, given the cost and organisation required to preserve a body for burial in another country, cremation offers a solution. The option of cremation became available in Samoa in 2013 when Letoa Sefo $\mathrm{Pa}^{\prime} \mathrm{u}$ built the first Samoa Crematorium (Samoa Observer, December 2013). In the context of Samoan notions of $f a$ 'asinomaga, traditional burial practices and Christian religious beliefs, many considered cremation a shocking choice, because of the belief that a body must be buried intact to await the Resurrection. Those people I interviewed, both young and old people, opposed the practice of cremation, saying it was a foreign influence, a business idea and an alien practice for Christian as well as Samoan proprieties or fa 'aSamoa. Many considered it disrespectful and contrary to Samoan customs, which 
dictate that a person should be buried in their customary land of their village. However some of my respondents, those who have lived overseas and were familiar with practice of cremation, thought it was an acceptable option. In Samoa the more educated people from among the urban elite were able to talk more openly about cremation. But when I asked my 85 year old mother's opinion, she replied, "Oka, e pei o le lè alofa lena i se matua, le susunu / 'Wow, it seems it's not loving one's parents if you burn them'." When talking with people about their views on cremation, like my mother, many used the word susunu 'to burn' - they were unaware of the polite term fa' aliuefuefu 'to cremate (lit. 'to turn to dust/ashes)'. However, after the practice was explained my mother said she was open to anything, joking "whether thrown in the open sea or cremated, it doesn't matter, as long as [I] am taken back to Samoa". She recognised that whatever was done with her mortal remains had to take account of her geographically scattered family.

Letoa told me it was the 2009 Tsunami that hit Samoa in September, which gave him the incentive to establish a crematorium. He said a number of foreigners had died in this tragedy and their families wanted their remains cremated and their ashes sent home, but this was not possible at the time. He subsequently planned the design and construction of his crematorium and sought a loan of around 1.5 million talä (USD 625,000) to finance it. (Samoa Observer, November 2013). ${ }^{6}$ He obtained government approval and applied to the Minister of Natural Resources and Environment for land and was given three acres to lease in 2012 next to the new cemetery at Taifa'igata (Fig. 4).

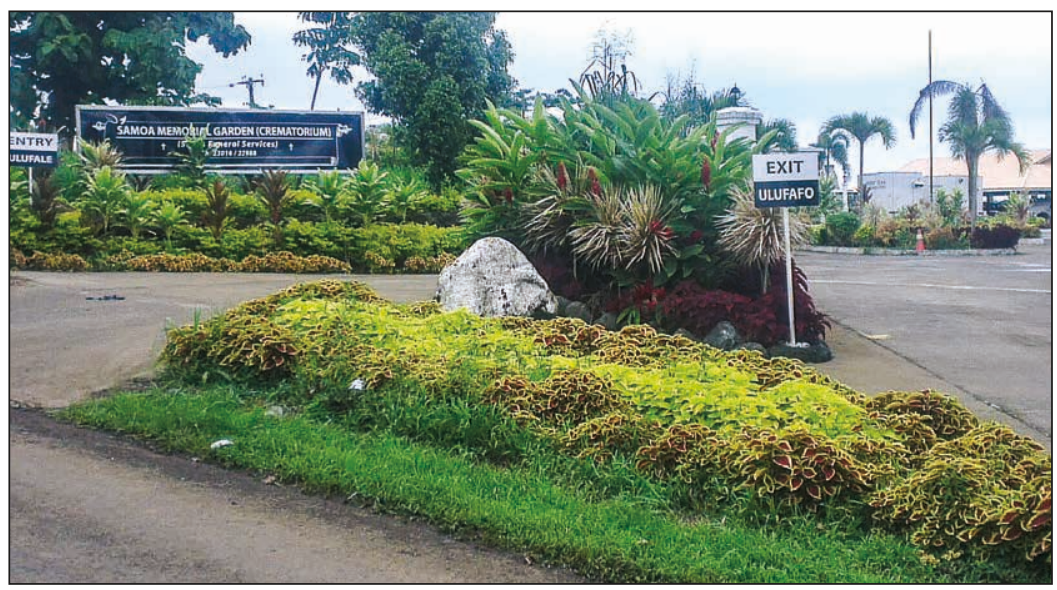

Figure 4. First Samoan crematorium at Tafa'igata. 
Speaking of the reaction by the public in Samoa, Letoa and Ana said that their first clients were foreigners who had died in Samoa, as well as some part-Samoans. They explained:

When we first opened there was resistance from the community saying 'this is not Samoan, what have we come to?' But we have had some Samoans, mainly those who have been overseas, for example a parent who returned to stay then died while here. The children came to cremate their parent and took the ashes with them to New Zealand, despite what the 'aiga here said. We [also] had a Tongan lady who died here, she was cremated and then the ashes were taken to Tonga.

We have had a case where the mother, who was Indian, married to a Samoan [her husband passed away a few years before her] and she wished to be cremated, but the children who live overseas did not want her to be cremated. They were adamant about it because they are part Samoan and they didn't feel it was right. They asked about the cost of embalming and air ticket to take the corpse to New Zealand, it was almost $\$ 20,000$ talā, compared to $\$ 8,000$ talā if cremated. After some reflection they went with their mother's wishes and they scattered her ashes at Aleipata [village]. They had a beautiful funeral for their mother with a reception and all the friends and relatives came to it.

We had cases with bank repossession of... freehold land... where a family buried a parent or sibling on the property, then they fall behind with their loan payments and the bank took the property back and had to sell. We have done exhumations for people overseas and we reinterred them wherever they tell us to. Now that we cremate we can send the ashes too if they wish. [We have done cremations for] for about 20 people... especially for those who had lived overseas.

While I was in Samoa, a funeral was announced, to be followed by a cremation. The announcement, after expressions of sadness, said that the deceased person, the wife of a chief, was to be taken from Sefo's funeral home and to the crematorium at Tafa" igata for her final service with "modern practice of burial". This was polite way of describing cremation, and the announcement also said "Taofi le malo" (meaning there would be no si ' $i$ alofa 'traditional gifts'). Ana Pa'u explained that in this case:

The couple had moved to Los Angeles in the 1970s and have lived and worked there, and the children were born there and have families. The father decided to move back to Falefā his home where he is matai, when he retired a few years ago. His wife, mother of the kids, goes back and forth between their Los Angeles home and Samoa where her husband lives. During this trip she became sick and sadly died. The families in Samoa had a meeting and her (own natal) family agreed to have her buried at her husband's place at Falefā. However, when the children arrived from America, they wanted to have a piece of their mother and convinced the father and related families to 
cremate their mother, that way each of the three children can take a quarter of her ashes and leave the other quarter for the father in Samoa!

This and other cases, as described by Letoa and Ana, reveal how decisions about cremation are beginning to be modified. Some people feel that Samoan beliefs and religious attitudes to death share very similar views about the sanctity of the body. Some perceive cremation as the secularisation of death and as an insult to sacredness of the person in death. To speak of a person's death carries with it a "sense of tapu (forbidden), sā (protected), or mamalu (dignified) as a protective boundary that acts as its unseen guardian" (Seiuli 2013: 2). However, it is evident that some Samoans are pragmatic about change. Shortly after the opening of the crematorium, a relative of mine reported that the Government had agreed in Parliament on a policy to disallow interference with the cremation of a body, in recognition that it is an individual decision, and not a group or 'aiga decision. ${ }^{7}$ The Prime Minister also noted in a speech given at the opening of the Crematorium, that cremation was a good solution given the shortage of land for burying the dead. ${ }^{8}$

Over the last two decades among New Zealand Samoans cremation is has become an increasingly frequent choice for families who are geographically separated in Samoa and several other countries. For example, a senior and respected educator retired and moved to be with his children in Wellington, New Zealand. When he died aged 89 he was cremated. Another instance was more problematic. In July 2015 I interviewed Ta'efu, an orator who had travelled to New Zealand with the Samoan Rugby Team to perform the proper fa 'aSamoa protocols. During his stay he attended the funeral of a matai 'titled person' of his 'äiga as an orator representing this family resident in Samoa. He told me that he was shocked when a spokesman for the 'aiga of the deceased living in New Zealand announced at the funeral that a matai of Ta'efu's own 'aiga was to be cremated instead of buried. Nonetheless, he accepted the decision of the New Zealand family.

I turn now to my own recent experience to demonstrate how these decisions are made. I live in Hawai' $i$ and have close relatives including a sister and an older brother in Wellington, and other close relatives in Auckland. In 28 December 2015 our mother passed away, 35 years after our father passed away. She had moved there to seek medical treatment and had been living with one of my sisters in near Wellington for nearly two years. I was close to my mother and visited her in Samoa and later in New Zealand every year. I knew, as did others in the family, that her deepest ties and connection were to her village home in Samoa. But, like many people in Samoa, she did not have a will. Yet we all knew she would like to be taken back. The family had gathered for her 85th birthday in Wellington. Before our arrival she had been in hospital for a week and the doctors thought she did not have 
long to live, but she recovered briefly during the time we were there. But in her final days, no family-wide decision could be made because we were so geographically dispersed (Hawai'i, Mainland United States, Australia, New Zealand, New Caledonia, American Samoa and Samoa). The decision was made for cremation because it was the most rational thing to do, to both delay the funeral so we could assemble in New Zealand and to allow her remains to be taken home to Salelologa, as her final resting place. She was a devout Catholic who wholeheartedly believed in the redemption and eternal life that come as a reward for ones actions and deeds in life, and not necessarily through interventions on one's behalf through prayers and masses during one's funeral. Discussions with the priests and one of my sisters, a Catholic nun, provided words of comfort. They explained that the Church has long gone beyond doctrines opposing cremation, and that the Church now allows people to donate organs if they wish upon death. Her soul and spirit were what was important and her remains, whether reduced to ashes or buried in the ground, were a manifestation of our physical bonds.

We spent our last five days with her at Te Mangungu Marae when she was brought there and laid in state, allowing our fa' aSamoa mourning rites to be observed there. On the last day of her funeral mass, we invited everyone who attended her Requiem Mass to come to the marae for a luncheon buffet in her honour. We showed slide presentations of her life and 'aiga, and the grandchildren danced as part of the afternoon activities. At the marae we stayed together: cooking, eating, praying, sleeping, and practicing songs, dances and eulogies for her funeral, cementing the bonds of family. The farewell rites we had for her in New Zealand allowed us to visit her for two weeks at the funeral home - saying our prayers and singing our family's favourite inter-denominational hymns.

The decision for cremation allowed us to plan a ceremony to return her ashes to Salelologa in 2017 when a memorial service would allow our relatives and 'äiga to gather in Samoa to honour her and her wishes to be buried with our father. Moreover, the second memorial service planned in Samoa will celebrate her life and will honour both our parents with all their children and grandchildren and other relatives in families in attendance, so that it will also be a family reunion. Despite these practical considerations, some family members felt that a full Samoan funeral should have been held, befitting her rank, family connections, career and other life achievements, and that we had not fully considered cultural and religious imperatives. Others pointed out that her remains are still present in an urn, which can still be buried in the soil of her home place. 
My recent personal experiences have helped me illustrate how funeral fa' alavelave have adapted to changes in the cultural, social, economic and political life of Samoans, particularly in relation to the diaspora. I have shown that there has been a blending of indigenous concepts of caring for the dead and modern practices in relation to the remains of the dead. Today they push the boundaries of social hierarchy that structure Samoan life, as in the saying, "O Samoa o le atunu'u ua 'uma 'ona tofi /"the foundations and positions of Samoa have been apportioned", referring to the expectation that people know their place and social position, which includes their anticipation of their eventual burial and gravesites. This saying refers to the privileges of chiefs described in this paper (see also Meleisea and Schoeffel in this volume) that have been in a sense democratised by modern and Christian notions that families may choose to honour the dead with rites once reserved for the highest chiefs. Funerals rituals have become more complex with ongoing processes to ensure that the dead are not separated from the living and despite the economic costs they impose, they are also a means to build social capital. I predict that most people will come round to the practice of cremation and that acceptance will not mean secularisation or weakening of Samoan customs. However it is an interesting topic for further research to find out what the attitudes are in other mainstream churches such as the Congregational Christian Church of Samoa, the Church of the Latter Day Saints (Mormon) and the Methodist Church in Samoa. Cremation will not mean secularisation or attenuation of Samoan customs. If these churches allow it, it is likely to become an increasing adaptation of fa 'aSamoa as has been the case with other aspects of funeral practices, and as Samoan families continue to expand transnationally.

\section{ACKNOWLEDGEMENTS}

My paper draws on research conducted in July 2014, December 2014, November to Dec 2015 and January 2016 in Hawai' 'i, Auckland and Wellington, and in March 2015 and August-September 2015 in Samoa. Fieldwork strategies included interviews, participant observation and focussed interviews conducted in Apia and Salelologa, as well as in Auckland and Wellington and Honolulu. In explaining the changes in shape and form of fanuaoti or tu 'ugamau 'graves', burials and funerals, I draw also on my personal experience of funerals and their transformation both as a participant deeply involved in the process as well as an observer in the field. 


\section{NOTES}

1. Sunia notes that the 'ie o le mavaega is not meant to be reciprocated, or returned to the in-laws who brought these to pay respect, but the 'ie o le amiga 'finemat for fetching the widow/widower' and the 'ie o le fa 'amagaloga 'finemat for forgiveness' should be returned. The orator at the staff, like master of ceremony, must explain there is no need for a pardon and forgiveness fine mat, for the wife (or husband) has more than paid and worked hard in serving her husband (or his wife) and family. Likewise, in the 'ie o le amiga there is no need for fetching the mother of the children back to her natal famil, she is family now. This is true especially if they have children.

2. The se 'e is similar to tamasā which is synonymous with feagaiga 'sacred covenant between brother and sister'. In Tutuila and Manu'a they use the word tamasā.

3. Sunia (1997) explained the difference between faigāleo in old times; it was to chase away demons and bad spirit, whereas faigäleo today is to console and make the journey of the deceased spirit safe to that resting place/paradise in the Christian sense. With the morgue, the pastor and choir of the deceased would attend the service at the morgue, or the prayer service at the home if the corpse is there overnight. This is done several times: at arrival, in the evening and in the morning before the body is taken to a church for the final service, and finally at the burial site. At reciprocation, this group should get more of the meaalofa 'gifts'.

4. Most villages in Samoa have ali 'i gravesites in paepae 'platform of stones', nowadays most tia and graves are made with cement. Aumua and most elders say in precolonial Samoa, people were buried near their own houses because those living there wanted to have them nearby. But then the missionaries and colonial governments arrived and urged having cemeteries for each village on its outskirts for health reasons, which the New Zealand Administration also enforced. Most villages have a cemetery but whether this rule is enforced is another question. Lepea Village is one village where this rule is strictly adhered to this day.

5. Generally, it is believed that it was something popularised by Samoans in Tutuila, American Samoa, during unveilings. It is usually a form of expressing love for the deceased, but the excesses of it have been blamed for burdening families; the same can be said of almost any fa 'alavelave taking place in American Samoa, which gradually made its way to independent Samoa.

6. This was the first crematorium in Samoa.

7. This was probably enacted to protect individuals from village interference, since there was a lot of criticism from the village matai councils when it first opened.

8. The first modern mass grave was dug in Tafa'igata. This mass grave was used to bury all the unidentified people who died in the 2009 Tsunami. It was also where the new public cemetery was located. It is also the same land where Sefo $\mathrm{Pa}^{\text {'u's }}$ 's crematorium is located. Another instance of a mass grave was during the Great Influenza Epidemic of 1918, during the New Zealand Administration of Samoa as a Mandated Territory, which is said to have killed one-third of Samoa's population. 


\section{REFERENCES}

Bourdieu, Pierre, 1984. Distinction: A Social Critique of the Judgement of Taste. London: Routledge and Keagan Paul

Meleisea, Malama, 1989. The Western Samoa migration quota and New Zealand's regional role in the Pacific. Population Review 15 (1): 68-74

Samoa Observer, November 2013.

Samoa Observer, December 2013.

Seiuli, Byron, 2013. Gapatiaga i le maliu: How do Samoan men and their families deal with death and bereavement? Health Research Council of New Zealand (HRC), Pacific News, December 2013.

Simanu, Aumua Mata 'itusi, 2002. O Si Manu a Alii. Honolulu: University of Hawai'i Press.

Simanu-Klutz, M. Luafata, 2001. 'Aumua Mata'itusi Simanu: Life History of Samoan Educator and Orator in Diaspora. Unpublished MA thesis, Pacific Islands Studies, University of Hawai' $i$ at Mānoa.

Sunia, Fofo, 1997. Lupe o le Foaga. Utulei: American Samoa.

\section{ABSTRACT}

Of the most important ritual events among Samoans, referred to as fa'alavelave, funerals are often the most elaborate. In this article, I examine the factors that influence decisions about graves and the location of grave sites, and the most recent option of cremation, rather than burial, in the context of migration and social change. I also argue that place as identity is intimately bound up with conceptions of kinship that define where the 'aiga (extended family, kindred) are buried, fa 'asinomaga (identity, belonging) and fanua (land).

Keywords: burial practices, cremation, diaspora, place, Samoa

\section{CITATION AND AUTHOR CONTACT DETAILS}

Lilomaiava-Doktor, ${ }^{1}$ Sa 'iliemanu, 2016. Changing Morphology of Graves and Burials in Samoa. Journal of the Polynesian Society 125 (2): 171-186; DOI: http//dx.doi. org/10.15286/jps.125.2.171-186.

${ }^{1}$ Corresponding author: Hawaiian-Pacific Studies, University of Hawai' $\mathrm{i}$ - West O‘ahu. 91-1001 Farrington Highway, Kapolei, HI 96707, United States of America. Email: sailiema@hawaii.edu 